\title{
Horticultural nurseries and nematode dissemination
}

\author{
K. Poornima and R. K. Walia*
}

Horticultural nurseries are often contaminated with nematodes, especially the root-knot nematode, Meloidogyne spp. Nematodes are concealed in the roots of planting materials (plantlets in polybags). Due to unawareness about nematode infection in planting materials among nurserymen, growers and horticulture field staff, the nematodes have spread across India. The infected plants often do not grow well and slowly succumb to nematode infection on roots that is accentuated due to secondary attack by fungal (Fusarium spp.) pathogens. Recently, this problem has cropped up in a big way in guava plantations across the country and a suspected exotic species, Meloidogyne enterolobii (the guava root-knot nematode) has been intercepted in 11 states. Methods to contain nematode infection in nurseries and prevent further spread through planting material are suggested in this study.

Keywords: Horticultural nurseries, dissemination, guava, planting materials, root-knot nematode.

THE spread of nematodes to distant areas through infected planting materials in not new. There are numerous reports that highlight the introduction of exotic pests and diseases trespassing continents and international barriers, despite the quarantine set-up in place ${ }^{1}$. Introduction of golden nematode of potato from Europe to South India is well known. To check its further spread in the country, domestic quarantine against a nematode pest was promulgated for the first time (the Destructive Insects \& Pests Act, 1914 Act No. ii of 1914; Plant Quarantine Regulation of Import into India Order, 2003).

Incentives offered under the National Horticulture Mission are aimed to promote diversification towards horticultural crops. Consequently, farmers are shifting to protected cultivation systems, floriculture and fruit crops. Over the last decade, the area under horticultural crops has grown by $2.6 \%$ per annum ${ }^{2}$. This has led to the unhindered and unchecked inter-State movement of planting materials from nurseries to farms. Unfortunately, this commercial activity is also contributing towards dissemination of nematodes through infected planting materials, especially in fruits like guava and pomegranate. Recently, scientists involved in the ICAR-All India Coordinated Research Project on Nematodes (AICRP-Nematodes) have intercepted cases wherein nematode-infected planting materials originating from reputed private/public

K. Poornima is in the Department of Nematology, Tamil Nadu Agricultural University, Coimbatore 641003 , India; R. K. Walia is in the ICAR-All India Coordinated Research Project (Nematodes), New Delhi 110012 , India.

*For correspondence. (e-mail: raman261156@gmail.com) nurseries and used to establish new orchards, have caused heavy plant mortalities inflicting economic losses to farmers.

According to a recent estimate in India, the losses in 19 horticultural crops were assessed at Rs 50,224.98 million annually ${ }^{3}$. Nematode problems in fruit crops originate at two stages. First, through infected planting materials from nurseries and secondly, from the main field soil; the former inflicts more damage. The basic problem is unawareness about nematode infection in planting materials among nurserymen, orchardists and officers of the State Horticulture Departments; and non-implementation of phytosanitary regulations by the concerned agencies. In this article, we focus on this serious issue of nematode dissemination through planting materials (showcasing the guava root-knot nematode as an example) occurring unabated on a large-scale and warrant urgent steps at the level of all stakeholders.

\section{Genesis of the problem}

During the last few decades, many growers have established new guava orchards by procuring elite varieties from reputed private/public nurseries. Except in the eastern parts of India, area under guava plantation has increased significantly throughout the country; from a mere 94,000 ha during 1991-92, it has increased to 154.6000 ha during 2001-02, and further to 264.9000 ha during 2017-18 (ref. 2). Reports of plant mortality in young plantations started emanating from many areas, particularly from Andhra Pradesh, Telangana, Tamil Nadu and Rajasthan. 


\section{Box 1.}

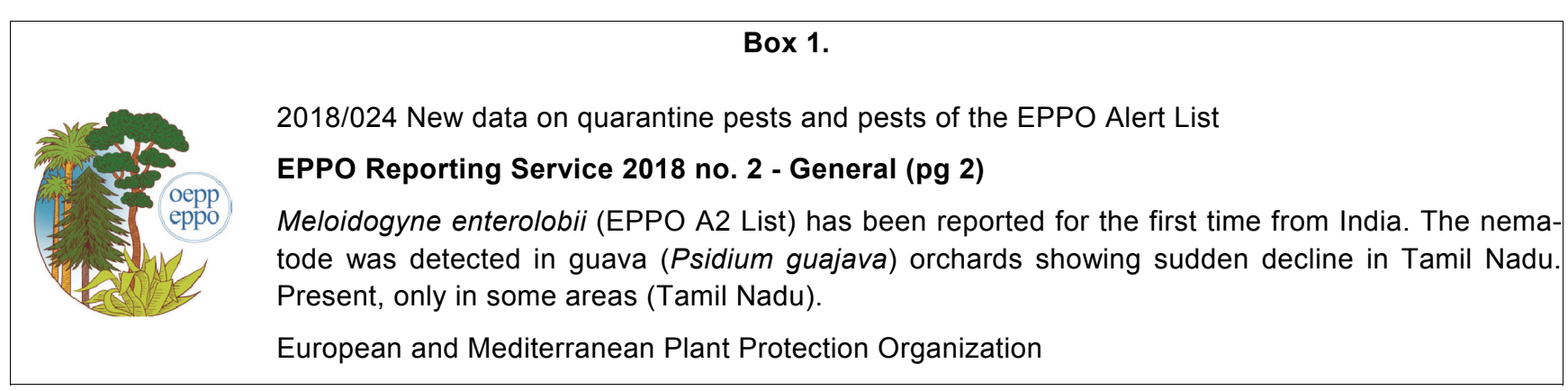

The ICAR-AICRP (Nematodes) has a network of 24 regular and voluntary centres in the country and operates through dedicated nematologists located at the State Agricultural Universities (SAUs). The major aim of the project is to address nematode problems of crops in different agro-climatic regions of India and develop management technologies for the same. The diseased/dead guava plant samples received by AICRP (Nematodes) centres at the Tamil Nadu Agricultural University (TNAU), Coimbatore; National Institute of Plant Health Management (NIPHM), Hyderabad, and SKN Agriculture University (SKNAU), Jaipur, in particular, highlighted the widespread and heavy incidence of root-knot nematode coupled with root rot among 1-2-year-old guava plants. On-site visits by scientists helped in better understanding of this complex problem. However, the scientists were baffled by the intensity as well as frequency of the disease and the extent of plant mortality that was never witnessed before.

\section{Nematode pest diagnosis}

Meloidogyne spp. are found worldwide in tropical and subtropical regions. Till recently, Meloidogyne incognita and Meloidogyne javanica have been reported associated with guava from various parts of the country ${ }^{4,5}$; however, these were not considered highly pathogenic to guava. The situation became alarming with the interception of a presumed exotic species of root-knot nematode, Meloidogyne enterolobii (synonym M. mayaguensis) on guava in Ayyakudi area, district Dindigul, Tamil Nadu' Excerpts of this report by European and Mediterranean Plant Protection Organization (EPPO) are reproduced in Box 1.

M. enterolobii, the guava root-knot nematode is assumed to have been introduced into India along with planting materials from some other country. Subsequent surveys revealed its occurrence in many districts of Tamil $\mathrm{Nadu}^{7}$ besides ten other states, namely Karnataka ${ }^{8}$, Uttar Pradesh, Rajasthan, Madhya Pradesh ${ }^{9,10}$, Uttarakhand ${ }^{11}$, Delhi $^{12}$, Andhra Pradesh, Telangana, Gujarat, Kerala, Haryana and West Bengal (reported from AICRPNematodes centres).

\section{Zooming-in on epicentres of nematode dissemination in India}

All the centers of AICRP (Nematodes) prepared inventories (based on information provided by farmers) on the origin of guava nursery materials and locations where these were planted in their respective states, with detailed information on post-planting disease incidence. A clear picture on the cause as well as epicentre of the disease has emerged.

\section{Andhra Pradesh and Telangana}

Based on the feedback from guava growers as well as field inspections by NIPHM scientists, it was assessed that plant mortality ranged from $60 \%$ to $100 \%$ in the fields after planting. Thousands of hectares of guava orchards are severely affected by root-knot nematode in Andhra Pradesh and Telangana. In most cases, the nursery materials originated from reputed private nurseries located near Rajahmundry, Andhra Pradesh.

\section{Tamil Nadu}

Guava is cultivated on a large scale in many districts of the state, but the severity of the problem in Ayyakudi area attracted the attention of scientists of TNAU. Young guava trees witnessed heavy mortality (30-50\%) within three months of first appearance of the symptoms ${ }^{6,7}$. Private nurseries usually outsource planting materials from Rajahmundry. Small farmers generally procure planting materials through middlemen who supply them to the fields directly. There are several unlicensed and unregistered nurseries in Tamil Nadu which spread nematodes. Many government farms are also selling nematodeinfected materials, though they are ignorant of this fact.

\section{Rajasthan}

Tonk and Swai Madhopur districts of Rajasthan are popular for guava production since the last two decades. In the recent years, guava orchardists in Swai Madhopur district 
have been facing serious problem of root-knot nematode disease that was ultimately identified as $M$. enterolobii. This problem is more severe in 3-4-year-old orchards. More than $70-80 \%$ plants display symptoms of stunted growth, yellowing of leaves and galling on roots. Later, dieback of guava is seen in root-knot-infested plants due to involvement of the fungus Fusarium solani.

In Swai Madhopur district, over 6000 ha area is cultivated with a single guava variety 'Barf Khan Gola'. Of this, approximately 1000 ha is severely affected by $M$. enterolobii. Random surveys of nursery sales points in the district during 2017 revealed that $90-100 \%$ guava plants were infected with root-knot nematode. In 2018, over two lakh root-knot-infected plants were sold by local nurserymen to farmers of the district. The other sources of nematode-infected nursery materials are public sector institutions in Uttar Pradesh and Uttarakhand. During 2017, 70-80\% planting materials originating from Uttar Pradesh and used in various blocks of Swai Madhopur district were infected with root-knot nematode and $F$. solani.

The soil used in polybags by nurserymen in Uttar Pradesh for developing rootstock is infested with $M$. enterolobii. These root-knot-infected rootstocks are used for grafting with varieties Lalit and Pant Prabhat at Lucknow and Pantnagar, and variety Barf Khan Gola by private nurserymen in Lucknow.

\section{Other states}

The above information is just the tip of the iceberg. Adequate surveys could not be conducted in other states for want of manpower, but preliminary information reveals that the magnitude of the problem is same in other states as well.

\section{Why are horticultural nurseries getting infected by nematodes?}

Planting materials in horticultural nurseries are prepared in various ways. In some cases (pomegranate, olive, banana, etc.) disease-free tissue culture plants are raised in laboratories and then shifted to soil contained in polybags for root hardening for several months before planting in fields. Most of fruit plants, however, are propagated vegetatively.

Vegetative propagation methods include ground layering, air layering, rooted cuttings, cloning, etc. besides grafting. Ground-layered cuttings are more prone to nematode infestation than air-layered cuttings; the former have direct contact with the soil around the mother plant which may itself be infested with nematodes, while the latter does not. Sphagnum (moss) and root-promoting growth regulators (like indole butyric acid) are essential constituents of these techniques. Upon initiation of root- ing, the cuttings are established in 'native soil' filled in polybags for hardening. Many times the polybags are changed more than twice to accommodate the growth of plants and sometimes by different nurseries to which the plants are being transported.

All these operations are usually done within the premises of established orchards. Many times the potting mixture used to fill polybags is reused without sterilization/solarization. This 'native soil' which may be already contaminated with nematodes results in infected plantlets, and is the root cause of this problem. Concealed in black polythene bags are the roots of plants that are already infected with endoparasitic nematodes, and the balled soil contains ectoparasitic nematodes. Such plants are never inspected for nematode infection by the officials of various agencies or the customers, and are transported to farflung areas; thus nematodes also get introduced to newer places inadvertently ${ }^{13}$.

\section{Symptoms of nematode infection}

\section{In the nursery}

Thousands of black polybags bearing the planting materials are stacked together on the ground in horticultural nurseries. The appearance of plants (shoots) can be totally deceptive and may not manifest any symptoms of nematode infection. However, severely infected plants exhibit general symptoms of yellowing/bronzing in leaves, especially in case of guava (Figure $1 a$ ). However, diagnostic symptoms, i.e. root galls are not visible because these are concealed inside the polybags (Figure $1 b$ ). Neither the nurserymen nor the orchardists are aware of this. In order to confirm root-knot nematode infection, one has to tear open the polythene cover, remove the soil gently, wash the roots and look for conspicuous galls or minute bulges that may be microscopic (Figure $1 c-e$ ), especially in the case of ground layers (Figure $1 f$ ).

\section{After planting}

Severely infected plants may remain moribund after planting and do not pick up normal growth and sprouting. Slowly, the leaves start turning yellow, dry up (Figure $2 a$ ) and the plants defoliate showing bare twigs (Figure $2 b$ ). However, diagnostic symptoms can be seen on the roots. The whole root system may be variously galled (Figure $2 d$ ). With time, such galled roots start showing rotting symptoms (Figure $2 c$ ).

Guava wilt or guava decline manifests itself in two ways. First the plants dry up partially or completely (Figure $2 b$ ) within a couple of weeks, the guava wilt, which is typically caused by Fusarium spp. ${ }^{14,15}$ with or without the involvement of nematodes. Second, the plants start drying up slowly with leaves turning yellow, shedding of 

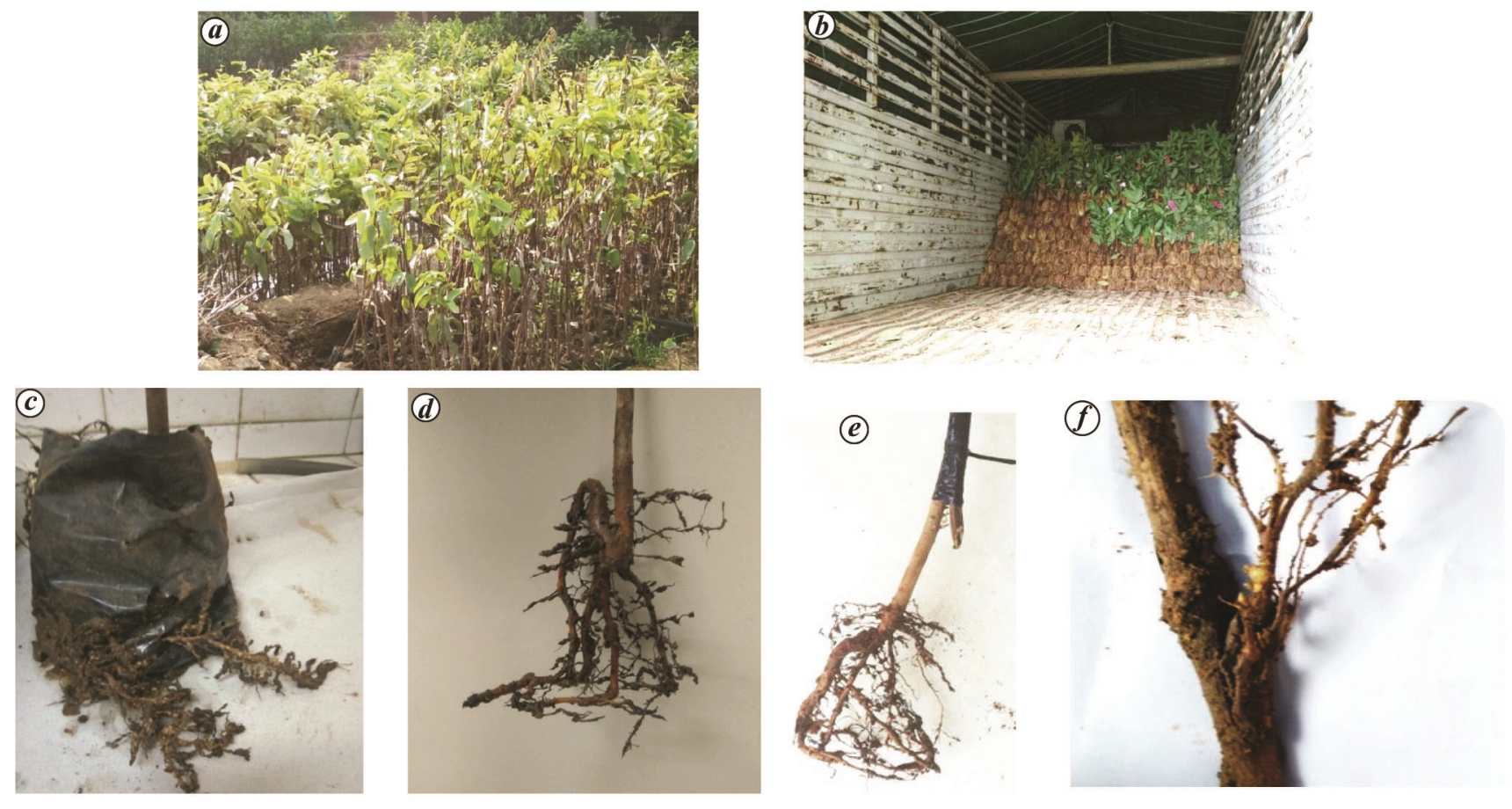

Figure 1. Nematode symptoms at nursery stage (photographs courtesy AICRP-Nematodes, New Delhi). $\boldsymbol{a}$, Nematode-infected guava nursery material showing yellowing of leaves. $\boldsymbol{b}$, Truck loads of planting material being transported to different destinations. $\boldsymbol{c}$, Partially opened polybag of guava revealing nematode galls on roots (Krishnagiri district, Tamil Nadu (TN)). $\boldsymbol{d}$, Heavily infected roots of guava seedling. $\boldsymbol{e}$, Guava graft with galled rootstock (Coimbatore district, TN). $\boldsymbol{f}$, Roots of guava ground layer showing minute galls (Theni district, TN).

leaves, and plant mortality occurs gradually over a period of a few months, the slow wilt or decline, that is typically caused by the root-knot nematode.

\section{Guava decline or guava wilt: the disease complex}

Studies conducted in Brazil clearly established that major root rot and a negative effect of all variables were observed in the guava seedlings inoculated with $M$. mayaguensis $(=$ M. enterolobii) and four Fusarium solani isolates ${ }^{16}$. This characterizes guava decline as a complex disease caused by the synergistic effect of these organisms, in which parasitism by the nematode predisposes the plants to root decay caused by the fungus.

We firmly believe on the basis of studies conducted at TNAU and elsewhere that this is disease complex and has to be addressed likewise. Misra ${ }^{17}$ has also mentioned that guava wilt is a complex problem wherein nematodes aggravate the disease.

\section{Raising nematode-free planting material}

\section{Nematode-resistant rootstocks}

One of the best methods is to raise nematode-free planting materials, but unfortunately there are no root-knot nematode-resistant rootstocks available in case of guava and pomegranate. All the cultivated varieties of guava that are used as rootstocks for grafting are either susceptible or highly susceptible to guava root-knot nematode ${ }^{18}$. Locally available wild seedlings can be used as rootstocks for grafting as they would often have natural resistance against nematodes.

\section{Tissue culture plants}

Tissue culture plants offer the guaranteed material that is free from all pests and diseases. But such plants are available in select cases only, for example, pomegranate, banana and citrus, whereas it is not so in case of guava.

\section{Using soil-less medium}

Use of sterilized coir pith, cocopeat or vermiculite instead of native soil for hardening of rooted planting materials will add a little to the cost, but will provide absolute nematode as well as disease-free planting materials. However, application of nutrition will be required whenever soil-less media are used.

\section{Air layering}

This is a safe method of vegetative propagation and can be used in guava propagation. The rooting medium used 

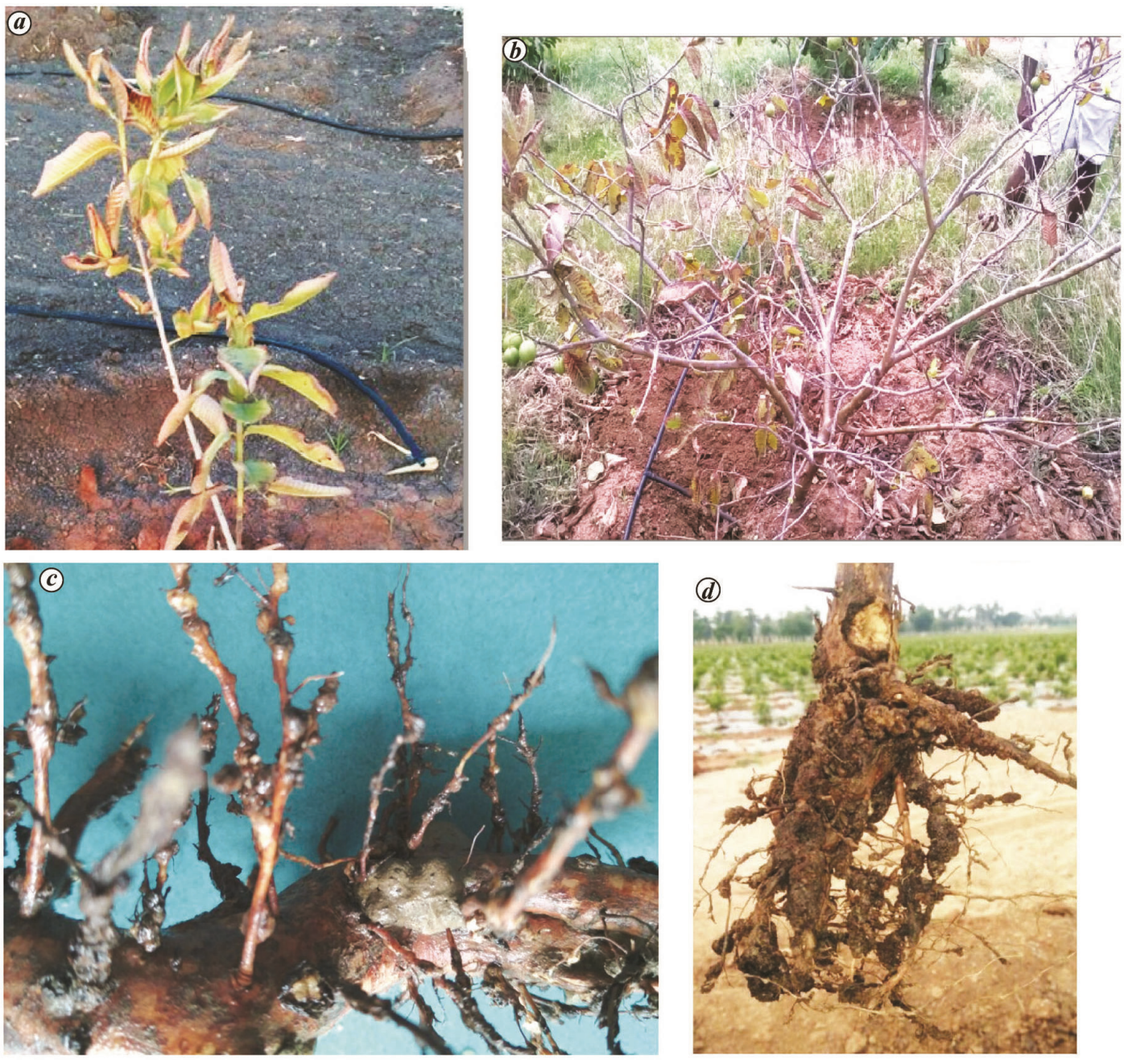

Figure 2. Symptoms on guava after planting in the field (photographs courtesy AICRP-Nematodes, New Delhi). $\boldsymbol{a}$, Bronzing and drying of leaves in a newly transplanted guava graft (Theni district, TN). $\boldsymbol{b}$, Plant mortality due to fungal infection predisposed by guava root-knot nematode (Dindigul district, TN). $c$, Guava roots with galls caused by root-knot nematode and rotting due to fungal infection. $\boldsymbol{d}$, Profusely galled roots in a one and a half year old guava plant (Lucknow 49).

in layers is soil-less and can be bio-fortified to ensure further protection. The rooted cuttings can be shifted to sterilized medium for hardening and further growth of plants.

\section{Using nematode-free soil for root hardening}

Under the present circumstances, there seems to be no better option than getting the soil rid from plant parasitic nematodes. The bulk soil to be used as hardening medium can be alleviated of plant parasitic nematodes by several methods, each having its own advantages and disadvantages.

- Use of chemicals such as formaldehyde, hydrogen peroxide to treat the bulk soil.

- Solarization of soil in the open. Use of thin transparent polythene sheets for about 2-3 months during peak summer is effective and may be used as a routine good horticultural practice.

- Solarization of soil/polythene bags filled with soil by covering with polythene sheets (double solarization).

- Use of virgin soil.

\section{Farmers' practices}

Some nurserymen have devised their own novel methods for obtaining nematode-free soil.

- Use of soil from virgin lands or dried-up ponds to fill the polybags.

- Rooted cuttings are made in sand medium under mist chambers and then transferred into larger polybags filled with sterilized soil (formaldehyde-treated) medium. 
- Soil sterilization using either formaldehyde or hydrogen peroxide (100 $\mathrm{ml}$ in 1 litre of water); soak it overnight followed by solarization using polythene sheets for 12-15 days before filling polybags.

- Use of soil-less media such as coir pith and vermiculite which are also drenched in either formaldehyde or hydrogen peroxide followed by solarization for few weeks to ensure nematode-free medium for filling polybags.

- Some farmers procure soil from paddy fields for filling polybags, solarize it for 2-3 months, fill it in polybags and again solarize the bags by covering them with polythene sheets for a month. Farmers consider that soil from paddy fields is unlikely to harbour nematodes that will attack other crops.

\section{Use of plant growth-promoting rhizobacteria}

Plant growth-promoting rhizobacteria (PGPR), e.g. Pseudomonas spp. and Bacillus spp. can be used to fortify the rooting media or potting media in nurseries. They give protection to the roots by producing nematoxic compounds.

\section{Use of bio-agents}

Nematode egg-parasitic fungi like Purpureocillium lilacinum (=Paecilomyces lilacinus), Pochonia chlamydosporia and broad spectrum bio-agents like Trichoderma viride, T. harzianum and Pseudomonas fluorescens can be multiplied in organic materials (farm yard manure, etc.) and incorporated in the potting media used for filling polybags.

\section{Nursery certification}

The certification of nursery planting materials must be enforced in letter and spirit by government agencies to ensure movement of nematode-free plants only. The infected materials must be discarded and destroyed.

\section{Initiatives taken by AICRP (Nematodes)}

The database prepared by AICRP (Nematodes) centres on the basis of field visits and feedback from growers unfolded the magnitude and intensity of the problem never witnessed before. Besides guava and pomegranate, we also have preliminary evidence of rare root-knot nematode spread in citrus (Meloidogyne indica) and mango (Meloidogyne spp.) through planting materials. Unawareness about nematodes and lack of above-ground diagnostic symptoms are the major bottlenecks in addressing this nation-wide problem. Therefore, AICRP (Nematodes) has prepared an action plan and launched a series of activities to address the problem for all stakeholders. The following initiatives have been taken.

- Creating awareness on raising nematode-free planting materials through regional workshops involving nurserymen, horticulture officers and orchardists. Several workshops were organized during 2017-18 in Andhra Pradesh (Kadiyam nursery hub), Tamil Nadu, Haryana, Jammu, Western Uttar Pradesh, Uttarakhand and West Bengal in collaboration with State Horticulture Departments and the respective SAUs.

- The Department of Nematology, TNAU has organized a series of one-day workshops to educate farm managers, officers in-charge of state horticultural farms, quarantine officers, nurserymen and Krishi Vigyan Kendra scientists on the identification of symptoms of nematode infection in nursery materials, and methods of raising nematode-free propagating materials.

- A Technical Bulletin on Nurserymen and Orchardists: Beware of Nematodes has been published in English, Hindi, Tamil, Bangla and Telugu, and distributed during the workshops.

- The TNAU centre of AICRP (Nematodes) has prepared a trilingual (English, Hindi, Tamil) video depicting the disease symptoms and its management in guava and pomegranate to educate all stakeholders through electronic media.

- On the initiative of AICRP (Nematodes), the matter was taken up with the Ministry of Agriculture and Farmers' Welfare (MoAFW), Govt of India (GoI), which in turn constituted a Committee of experts. The Committee has given its recommendations to the Ministry.

\section{Recommendations made by the committee to MoAFW, GoI}

- Mandatory use of sterilized substrate (potting media) for propagation (root hardening) of horticultural planting materials.

- A Committee under the chairmanship of Joint Secretary (Plant Protection), GoI was proposed to frame guidelines on plant protection component for enactment of nursery regulations and accreditation of nurseries to encompass the pest/disease management (including plant parasitic nematodes).

- A national workshop of senior officers of all State Horticulture Departments be organized at New Delhi to sensitize them on the issue of nematode dispersal through planting materials, and further technology package may be worked out for its prevention.

- Compulsory training of State Horticulture Officials and Accreditation Team Members in nematode disease diagnosis and remedial measures in horticultural nurseries. 
- Services of ICAR-AICRP (Nematodes) scientists to be extended for examining nurseries/planting materials and issue mandatory 'Health Certificate'.

- State-wise identification, cataloguing and abolition of unlicensed/unregistered nurseries.

- While according accreditation to nurseries, soil/media health may be ensured and more weightage in score card should be given in the guidelines.

- Regular monitoring of nursery materials by specially trained staff of State Governments and destruction of all nematode-infected planting materials/soil.

- Amendment of nursery laws/regulations to make provisions for issuing mandatory 'Health Certificate' by the concerned District Horticulture Officer to the registered nursery owner/carrier at the time of transporting planting materials from these nurseries.

\section{Future lines of interdisciplinary research to manage root-knot nematode fungal disease complex in guava}

(1) Identification of resistant rootstocks for $M$. enterolobii and Fusarium spp., such as Psidium friedrichsthalienum and additional Psidium spp. that would be compatible for grafting on Psidium guajava (probable sources being Latin American countries).

(2) Production of tissue culture plants in guava that would be devoid of nematode infestations.

(3) In vitro production of resistant guava plants through somatic embryogenesis.

(4) Production of planting materials such as rooted cuttings and clones should be perfected using sterile soil-less medium.

(5) Air layering as the standard method of production of guava, with emphasis on using sterilized hardening media.

1. EPPO, EPPO Technical Document No. 1061, EPPO study on the risk of imports of plants for planting, EPPO Paris, 2012, p. 75.

2. Anon., Horticulture statistics at a glance, 2018. Horticulture Statistics Division, Department of Agriculture, Cooperation and Farmers' Welfare, Ministry of Agriculture and Farmers' Welfare, Government of India, 2018, p. 458.

3. Kumar, V., Khan, M. R. and Walia, R. K., Crop loss estimations due to plant-parasitic nematodes in major crops in India. Natl. Acad. Sci. Lett., 2020; https://doi.org/10.1007/s40009-020-00895-2

4. Khan, M. R., Hassan, A., Ghosh, B., Das, B., Ghosh, S. and Ray, S. K., Diversity and community analyses of soil nematodes associated with guava from West Bengal, India. Acta Hortic., 2007, 725, 483-487.
5. Ansari, R. A. and Khan, T. A., Parasitic association of root-knot nematode, Meloidogyne incognita on guava. e-J. Sci. Technol., $2012,5,65-67$.

6. Poornima, K., Suresh, P., Kalaiarsan, P., Subramanian, S. and Ramaraju, K., Root knot nematode, Meloidogyne enterolobii in guava (Psidium guajava L.) - a new record from India. Madras Agric. J., 2016, 103, 359-365.

7. Ashokkumar, N. and Poornima, K., Occurrence and distribution of root knot nematode, Meloidogyne enterolobiiin guava (Psidium guajava L.) in Tamil Nadu. J. Pharmacogn. Phytochem., 2019, 8 , 1922-1924.

8. Ravichandra, N. G., New Report of root-knot nematode (Meloidogyne enterolobii) on guava from Karnataka, India. EC Agricult., $2019,5,504-506$.

9. Khan, R. M., Ahmad, I., Kumar, K. H., Singh, A. and Shukla, P. K., Infestation of Meloidogyne enterolobii in newly established/ old guava orchards and nurseries in Madhya Pradesh, Rajasthan and Uttar Pradesh. Ann. Plant Protect. Sci., 2019, 27, 170-171.

10. Singh, N., Emerging problem of guava decline caused by Meloidogyne enterolobii and Fusarium oxysporum f. sp. psidii. Indian Phytopathol., 2020, 73, 1-2.

11. Kumar, S. and Rawat, S., First report on the root-knot nematode Meloidogyne enterolobii (Yang and Eisenback, 1988) infecting guava (Psidium guajava) in Udham Singh Nagar of Uttarakhand, India. Int. J. Curr. Microbiol. Appl. Sci., 2018, 7, 1720-1724.

12. Kalaiarasan, P., Bhat, Chaitra G., Hada, A., Jaiswal, N. and Uma Rao, Molecular characterization of root-knot nematode (Meloidogyne enterolobii) parasitizing guava from IARI, New Delhi, India. J. Entomol. Zool. Stud., 2020, 8, 1247-1253.

13. Poornima, K. and Walia, R. K., Orchardists and nurserymen: beware of nematodes. All India Coordinated Research Project on Nematodes in Cropping Systems, ICAR, IARI, New Delhi, 2017, p. 24.

14. Ganeshan, K., Poornima, K., Renukadevi, P. and Nakkeeran, S., Synergistic effect of root knot nematode, Meloidogyne enterolobii and Fusarium oxysporum in causing guava decline in Tamil Nadu. Pest Manage. Hortic. Ecosyst., 2019, 25, 252-256.

15. Suresh, P., Poornima, K., Nakkeeran, S., Kalaiarasan, P. and Vijayakumar, R. M., Isolation and characterization of the causal organism of wilt in guava (Psidium guajava L.). J. Pharmacogn. Phytochem., 2019, 8, 1231-1235.

16. Gomes, V. M., Souza, R. M., Mussi-Dias, V., Da-Silveira, S. F. and Dolinski, C., Guava decline: a complex disease involving Meloidogyne mayaguensis and Fusarium solani. J. Phytopathol., 2010, 159, 45-50.

17. Misra, A. K., Management of guava wilt for improving productivity. In Doubling Farmers Income through Horticulture (eds Chadha, K. L. et al.), Astral International Pvt Ltd, New Delhi, 2017, pp. 451-461.

18. Ashokkumar, N., Poornima, K., Kalaiarasan, P. and Kavino, M., Screening and histological characterization of guava (Psidium guajava L.) cultivars against root knot nematode, Meloidogyne enterolobii. Pest Manage. Hortic. Ecosyst., 2019, 25, 84-92.

Received 24 April 2020; accepted 22 October 2020

doi: $10.18520 / \mathrm{cs} / \mathrm{v} 120 / \mathrm{i} 2 / 278-284$ 